\title{
Speaking the enemy language: the solitude of the missionary in calchaqui lands
}

\author{
Christophe Giudicelli[1]
}

\begin{abstract}
This paper analyzes the paradoxical simultaneity of the late acquisition of the Kakan language by missionaries and the brutal disappearance of the Calchaquí mission in the mid-1660s. The Jesuits came to master the Indians' language exactly at the time when it stopped being of any use to them, due to the mission's extinction and due to the deportation of its neophytes. This paradox thus calls for further analysis of the status of the now extinct Kakan language within the colonial linguistic economy. The Kakan was a vehicular language and became the enemy's language, associated with a territory (the Calchaquies valleys) and with a rebellious attitude. Its expansion dwindled over the age of settlement, whose agents promoted the colonial communication languages, and quéchua in particular. Finally, the dispersion of the inhabitants outside the valleys restricted the missionaries' linguistic knowledge to technical use, when they needed to communicate orders to the defeated calchaquies, then "friendly Indians" in the province militia.
\end{abstract}

Keywords: calchaquíes Indians; Tucumán Province missions; colonial languages.

\section{Falando a língua do inimigo: a solidão do missionário nas terras calchaquís}

\section{Resumo}

Este trabalho analisou um paradoxo: a sincronia entre a aquisição tardia do idioma kakán pelos missionários e o brutal desaparecimento da missão Calchaquí em meados dos anos 1660. Quando os jesuítas já falavam o idioma, esse conhecimento já não tinha nenhuma utilidade, pela extinção da missão e deportação de seus neófitos. Por sua vez, este paradoxo fez com que o estatuto de tal idioma, hoje inexistente, fosse investigado na economia linguística colonial. De língua veicular, terminou como o idioma exclusivo do inimigo, identificado como um território (os Valles Calchaquies), e como uma atitude rebelde. Sua extensão foi diminuindo conforme a colonização avançava, promovendo-se os idiomas de comunicação colonial, particularmente o quéchua. Por fim, a dispersão dos habitantes fora dos vales deixou aos missionários um conhecimento que serviria apenas para propósitos técnicos: transmitir ordens à milícia dos calchaquíes vencidos, alistados como "índios amigos" nas milícias da província.

Palavras-chave: índios calchaquíes, missões de Tucumã, idiomas coloniais.

\section{Hablar la lengua del enemigo: la soledad del misionero en tierras calchaquíes}

\section{Resumen}

Este trabajo analiza una paradoja: la sincronía entre la adquisición tardía del idioma kakán por los misioneros y la brutal desaparición de la misión de Calchaquí, a mediados de los años 1660. Fue precisamente cuando los jesuitas hablaban por fin ese idioma, cuando eso ya no les sería de ninguna utilidad, por la extinción de la misión y deportación de sus neófitos. A su vez, esta paradoja lleva a interrogar el estatuto de ese idioma, hoy desaparecido, en la economía lingüística colonial. De lengua vehicular, terminó siendo lengua exclusiva del enemigo, identificada con un territorio (los Valles Calchaquíes) y una actitud rebelde. Su extensión fue menguando conforme progresaban los idiomas de comunicación colonial - en particular el quechua. Por fin, la dispersión de los habitantes fuera de los Valles dejó a los misioneros un conocimiento que ya sólo les serviría para prestaciones técnicas: para la transmisión de órdenes a los vencidos calchaquíes, alistados como "indios amigos" de la provincia.

Palabras clave: indios calchaquíes, misiones del Tucumán, idiomas coloniales.

\section{Parlant la langue de l'ennemi: la solitude du missionnaire chez les Calchaquíes}

\section{Résumé}

Ce travail analyse un paradoxe: la simultanéité entre l'acquisition tardive de la langue kakan par les missionnaires et la disparition brutale de la mission Calchaquí, au milieu des années 1660. Au moment où les jésuites maîtrisaient cette langue, cette connaissance ne devait plus leur être d'aucune utilité, en raison de l'extinction de la mission et de la déportation de leurs néophytes. Ce paradoxe conduit en outre à interroger le statut du kakan dans l'économie linguistique coloniale. De langue véhiculaire, il finit par ne plus que la langue de l'ennemi, identifiée à un territoire (les Vallée Calchaquíes) et une attitude rebelle. Son extension se réduisit au rythme de la promotion des langues de communication coloniale - en particulier le quechua. Enfin, la dispersion des habitants en dehors des Vallées laissa à ces missionnaires une connaissance qui ne leur servit que pour des prestations de service techniques: la transmission des ordres aux vaincus calchaquís désormais «Indiens amis» dans les milices provinciales.

Mots-clés: indiens calchaquís, missions du Tucumán, langues coloniales. 
$\mathrm{T}$ his brief study is aimed at analyzing a paradox: the synchronism between the time when the missionaries of the Society of Jesus learned the kakán language, after decades of failed attempts, and the disappearance of the Calchaquí mission in the mid-1660s.

It was exactly when the Jesuits finally could master the language of the Indians in this mission that such knowledge was no longer useful for the administration of faith, due to the extinction of the mission itself and the deportation of its neophytes.

This leads us to question the status of this vanished language, originally spoken by the indigenous peoples of the Andean region of the Tucumán, generically called "diaguitas" by the Spanish, and soon divided into "diaguitas", "calchaquies" and "pulares", due to the advancement of the conquest front and the respective position of each one of these groups in the economy of the province's surveillance. ${ }^{1}$

It is worth to observe that the one considered to be the "general language" of the Tucumán in the late $16^{\text {th }}$ century began to be geographically and symbolically limited to the autonomous calchaqui territory, which resisted, for more than one century, all of the reduction intentions. From vehicular language, it became the enemy's language, identified with the rebel territory and attitudes during the whole first half of the $17^{\text {th }}$ century. Its regional expansion decreased as a result of the Spanish-creole colonization, whose agents actively promoted the languages of colonial communication - especially quéchua - in the lands they controlled.

In such conditions, the last ones to learn and practice kakán, besides natural-born speakers, were the Jesuits, because of their work in the Calchaqui mission from 1643 to 1658 . The war that began in 1658, among other reasons due to the maneuvers by Pedro Bohórquez, the "Tucumán Inca", as it caused the dispersion by military force of the populations that were, until then, autonomous in the Calchaquí Valley, radically changed the situation. The dramatic deportation of the Indians, spread across several locations of the four corners of the Tucumán and other nearby regions, left these missionaries without a mission, and their linguistic knowledge that would only be useful for technical activities: especially as troop interpreters, giving orders to the defeated calchaquies militia, who were an essential part of the troops of the "friendly Indians" of the province.

We will begin by the end of our story: the - announced - solitude of the last missionary of the calchaquies, father Hernando de Torreblanca, who reported the dramatic decline of his missionary work in the twilight of his life in the work Relación histórica de Calchaquí, written in 1696. However, this work was put aside and remained unpublished until the late $20^{\text {th }}$ century. ${ }^{2}$

'About this matter, see Christophe Giudicelli, "Encasillar la frontera. Clasificaciones coloniales y disciplinamiento del espacio en el área diaguito-calchaquí (S. XVI-XVII)", Tandil (Argentina), Anuario IEHS, n. 22, 2007, p. 161-212. ${ }^{2}$ A first version was published in 1984, however, the paleographic in charge was Archivo General de la Nación (AGN) in 1999. Both a responsibility of Teresa Piossek Prebisch. Hernando de Torreblanca, Relación Histórica de Calchaquí, Buenos Aires, AGN, 1999. [1696] 
In the mid-1660s, Colonial authorities had finally decided something that had been an obsession and a challenge for the Spanish domain for over one century: to definitely finish the Indians in the Calchaquí Valley, to take the desired valiserrano corridor of the Tucumán and to force the inhabitants to work on the productive sectors of the province. After really hard military campaigns, the governor Alonso de Mercado y Villacorta organized a new process in the zone of systematic expatriation of the inhabitants of that resistant area. A total of 12,000 people, according to his calculations, were distributed in the four corners of the province, beyond Santa Fé and to the borders of Río de la Plata. This number does not include hundreds of "pieces" divided among the soldiers who went to different locations of the Vice-Kingdom. ${ }^{3}$

If the campaigns conducted by Alonso de Mercado y Villacorta from 1659 to 1666 did not make the indigenous groups of the region disappear, unlike what was publicized for a long time ${ }^{4}$, they clearly brought - from the point of view of colonial power - a solution to the "calchaquí issue", after definitely bringing into submission the autonomous calchaquí territory to colonial obedience.

The case is well known: usually, the responsibility of this final conflict is attributed to the unexpected maneuvers of a very peculiar character, called Pedro Bohórquez, a.k.a. "the Tucumán Inca", "Pedro Huallpa", "White and blonde", 6 who was Andalucian at birth, however, a self-proclaimed descendant of the sovereigns of Cuzco; former failed discoverer of the Paititi, ex-convict in Valdívia, precisely because of his unfortunate enterprises in Peru; inventor of disposable cannons ${ }^{7}$, and, above all, an incomparable liar. ${ }^{8}$ In three years, he had been able to trick, at the same time, the Indians, the main nobles of the province, the governor himself and, finally, the Jesuits. To the first ones, he promised to put an end to oppression, thefts, slavery and the demands of encomenderos. To the second ones, on the contrary, he claimed he would not only conquer the submission of the rebels, but that they would also reveal to him the secrets of the gold and silver mines which they had been trying to find in vain since the foundation of the province. ${ }^{9}$ For the

\footnotetext{
${ }^{3} \mathrm{AGN}$, Collection “Manuscritos relativos a América” de la Biblioteca Nacional, Leg. 181, n. 853. "Real cédula para que a los indios calchaquíes no se les considere esclavos, 20 diciembre 1674".

${ }^{4}$ Rodolfo Cruz, "El fin de la "ociosa libertad". Calchaquíes desnaturalizados a la jurisdicción de San Miguel de Tucumán en la segunda mitad del siglo XVII", in, Ana María Lorandi (comp.), El Tucumán Colonial y Charcas, Buenos Aires, FFyL - UBA, 1997, T. II, p. 215-261; Lorena Rodríguez, Después de las desnaturalizaciones. Transformaciones socio-económicas y étnicas al sur del valle Calchaquí. Santa María, fines siglo XVII-fines del XVIII, Buenos Aires, Editorial Antropofagia, 2008; Christophe Giudicelli, “De la déportation à l'invisibilisation: la "dénaturalisation" des Indiens Calchaquís (Nord-ouest argentin), XVIle-XXIe siècle", in dossier "relocalisation et résilience autochtone", Recherches Amérindiennes au Québec 41(2-3), 2011, p. 61-82.

${ }^{5} \mathrm{AGl}$, Charcas 58, segundo cuaderno de los autos de Pedro Bohórquez, "Auto proveído por el gobernador Mercado y Villacorta, 8 de Julio de 1658", F. 53f-57v.

${ }^{6}$ AGI 122 , F 1 f, "Carta del gobernador Alonso de Mercado y Villacorta a la Audiencia de Charcas", 17-09-1657. ${ }^{7} \mathrm{AGI}, 122,1$ f, "Carta del Padre Juan de León al capitán Francisco de Nieva y Castilla, 24-06-1657".

${ }^{8}$ About this character, see Teresa Piossek Prebisch, Pedro Bohórquez, El Inca del Tucumán 1656-1659, Catamarca, Magma, 1999; Ana María Lorandi, De quimeras, rebeliones y utopías. La gesta de Pedro Bohorquez, Lima, Pontificia Universidad Católica del Perú, 1997.

${ }^{9} \mathrm{AGI}$, Charcas 58, primer cuaderno de los autos que se seguían contra Pedro Bohorques, FF 4v-5v, "Carta de Pedro Bohorques al capitán Hernando de Pedraza, 21-04-1657"; AGI, 122, 1 f, Carta del Padre Juan de León al capitán Hernando de Pedraza, 24-06-1657.
} 
latter, he painted the ideal picture of a more efficient - even though sui generis - evangelization, which had never been accomplished despite the several decades of work, and had made even the more patient workers of the Society desperate. Several Cartas Anuas had complaints, in an euphemistic way, about the scarce result of preachery: in 1612, the priests "[...] harvested only a few fruits [...]"; ${ }^{10}$ in 1635, "[...] the fruits did not correspond to the tiredness and care of the ministers of God [...]"; ${ }^{11}$ the one from 1641 claimed that "[...] the mission that had always performed among them, did not correspond to the fruit of the work". ${ }^{12}$ Finally, the letter from 1653 and 1654, immediately before Bohórquez's invasion, described, in similar terms: "[...] this mission, in which four clergymen live in captivity with more work costs than fruits of the foreign souls". ${ }^{13}$ However, it was infinitely more pessimistic against "[...] the idolaters of this valley [...] who [...] both physically and morally completely imitate the costumes of the most reckless savages". ${ }^{14}$ Besides, continued the writer of the same Carta Anua, they seemed completely decided to never admit the good news, ready to deny the faith to the few who left themselves to get convinced, "[...] returning to the vomit that would throw them to hell, and with that all threats are being frustrated, even the ones that usually convince the most servile souls".15

If one can perceive indeed a clear discouragement in this last official report, the vocabulary used in it did not diverge from what the "Jesuits' correctness" required. On the contrary, the personal correspondence of the missionaries who lived for many years in the Calchaqui Valley, in San Carlos and Santa Maria, was much harsher. Father Juan de Léon, for instance, did not mince his words when he became furious against "[...] those fools, dammed delinquents", in a letter sent to the encomendero Francisco de Nieva y Castilla. He even celebrated that, in an outrage not very consistent with the benevolent and quiet tone of the Anuas, that

[...] captain Pedro Calderón did very good to lead them with halters, and his only problem was not taking them to the end of the world, so that they could be locked up in prisons, because that would be the most adequate choice for their salvation. ${ }^{16}$

To make his point stronger, he professed something radical and not so charitable that, for the salvation of these diaguita Indians, who had been the

\footnotetext{
${ }^{10}$ Anua de 1612, Documentos para la Historia de Argentina, Buenos Aires, Instituto de Investigaciones Históricas Dr. Emilio Ravignani, FFyL, UBA, 1927-1929, T. XIX, p. 515

"Anua de 1635-1637, Documentos para la Historia de Argentina, Buenos Aires, Instituto de Investigaciones Históricas Dr. Emilio Ravignani, FFyL, UBA, 1927-1929, T. XX, p. 401.

${ }^{12}$ Anua from 1641-1643, Cartas Anuas de la Provincia Jesuítica del Paraguay 1641 a 1643, p. 57. The "few fruits" were mentioned by the provincial Nicolás de Mastrilli Durán to consider the first disappearance of the residence of the Calchaquí in 1623, “Carta al padre Nicolas Durán, Provincial Córdova, 1624", in Martín María Morales, A mis manos han llegado. Cartas de los P. Generales a la Antigua Provincia del Paraguay, MadridRoma, Universidad Pontificia de Comillas-I.HS.I, 2005, p. 312-313.

${ }^{13}$ Hernando de Torreblanca, Relación Histórica de Calchaquí, Buenos Aires, AGN, 1999. [1696], p. 136.

${ }^{14} / \mathrm{dem}$, Ibidem, p. 137.

15/dem, Ibidem, p. 143

${ }^{16} \mathrm{AGI}, 122,1$ f, "Carta del Padre Juan de León al capitán Francisco de Nieva y Castilla, 24-06-1657".
} 
leading actors of the "Great Rebellion" from the $1630-1640,{ }^{17}$ he declared that "setting them free was like giving a mad man a knife"."

Anyway, since the very beginning, the missionaries were amongst the most zealous supporters of the peculiar Inca, undoubtedly because in his arrival, they saw the possibility of achieving the long wanted conversion of the Indians, since they thought they could take advantage of the influence he had gained with his old catechumens. Out of the four missionaries, father Juan de León was, undoubtedly, the one who mostly believed in Bohórquez, and the least careful one when it came to referring to him in correspondences, using terms such as "our friend, general don Pedro", 19 "our good friend" ${ }^{20}$ and even "our Inca". It is true that this priest does not seem to have been the most grounded one, if we consider the principles of the triennial secret catalogs created by the same Society, ${ }^{22}$ which would explain the lack of care in his letters, so much that he would ask the addressees to burn them. These letters ended up being part of the judicial reports used against Bohórquez. ${ }^{23}$ The secret catalog of 1651 refers to him as ingenium mediocre, judicium exiguum, prudential parva and experiential rerum parva, and this worrisome evaluation was confirmed in $1656 .{ }^{24}$ Maybe his furious opinion against the Indians had been influenced by the fact that he was born in Santiago del Estero, in $1617,{ }^{25}$ that is, he had been raised, if not in hate, at least with the suspicion that all of the Spanish-creole had against the rebel Indian diaguitas and calchaquies.

It is to be observed that his brothers of religion, clearly less exalted - and better evaluated by their superiors - had followed the same path, using more moderate terms, that is right, but approving also without restriction the maneuvers of such a strange character. The superior of the mission, father Eugenio de Sancho, had written to the governor in the same way, ${ }^{26}$ while Hernando de Torreblanca, also creole and son of an encomendero of Córdoba, ${ }^{27}$ who had worked in all of the circumstances as a bilingual intermediary, defended the interests of the eccentric neo-Inca project of Bohórquez.

\footnotetext{
"7Aníbal Montes, “El gran alzamiento diaguita”, Revista del Instituto de Antropología, Universidad del Litoral, Rosario, n. 1, 1961, p. 81-159.

${ }^{18} \mathrm{AGI}, 122,1$ f, “Carta del Padre Juan de León al capitán Francisco de Nieva y Castilla, 24-06-1657".

$19 /$ dem, Ibidem.

${ }^{20} \mathrm{AGI}, 122,1 \mathrm{f}$, “Carta del Padre Juan de León al capitán Hernando de Pedraza, 24-06-1657".

${ }^{21} / \mathrm{dem}$, Ibidem.

${ }^{22}$ For a detailed analysis of the catalogues, and more, of the missionaries of the Jesuit province in Peru, see Aliocha Maldavsky, Vocaciones inciertas. Misión y misioneros en la provincia jesuita del Perú en los siglos XVI y XVII, Madrid, CSIC, 2012.

${ }^{23} \mathrm{AGI}, 122$, F 2 v, “Carta del Padre Juan de León al capitán Francisco de Nieva y Castilla, 24-06-1657”.

${ }^{24}$ These are found in ARSI, Paraquaria 4-1, F 167 et seq y 192 et seq.

${ }^{25}$ Catálogo trienal de 1644, ARSI, Paraquaria 4-1, F. 142 f et seq.

${ }^{26} \mathrm{AGl}$, Charcas 58, Primer cuaderno de los autos que se seguían contra Pedro Bohórquez, FF 3f-3v, "Carta del P. Eugenio de Sancho", 19-04-1657.

${ }^{27} \mathrm{He}$ was born in Córdoba, on September 13, 1613, and he was the son of Juan de Torreblanca, Portuguese encomendero suspected to be a Judaizer, which raised an investigation about the purity in his blood. Martín Morales, op. cit., p. 416. More bibliographic data in Carta Anua de 1689-1700, summarized by Carlos Page, "La evangelización jesuita del Valle Calchaquí. Hacia la idealización de un nuevo hábitat jesuítico-calchaquil", Tempo da Ciência, vol. 17, n. 33, $1^{\circ}$ semestre 2010, p. 44 (p. 25-55).
} 


\section{Interpreter and mediator: the voice of the Inca}

In order to gain such persuasive strength, Don Pedro Huallpa necessarily had to have great eloquence, which had amazed - or mesmerized all of his interlocutors. Curiously, even though he spoke in Castilian with the encomenderos, the civil authorities and the fathers of the Society of Jesus, he did not know kakán - the language of the Indians who sheltered him - and he could not communicate in quechua either, the language of the Tawantinsuyu, whose reborn dynasty he claimed to embody. This fact leads to the - posterior - astonishment of the lonely missionary we are talking about, Hernando de Torreblanca, as hi himself recognized:

[Pedro Bohórquez] tried to cause the rebellion of the Indians so that he could be named "Inga": and one can admire, in this mess and fantasy, the fact that he did not know the general language of the Ingas, which is Quichua, not even the one of the Calchaqui country, using only an interpreter. ${ }^{28}$

\section{In three years, he had been able to trick, at the same time, the Indians, the main nobles of the province, the governor himself and, finally, the Jesuits}

It is true that Torreblanca had some motives to be amazed by such a paradox: as he had been one of the missi dominici of Bohórquez, and he had worked hard to favor the installation of the Andalucian Inca in the heart of the Calchaquí Valley, in Tolombón, close to his mission, in San Carlos, persuading the governor, in top of it all to let him officially bear the title of "Inca", besides "general lieutenant", head of justice and war captain in the Calchaqui, its lands and jurisdiction. ${ }^{29}$ Torreblanca expresses himself approximately 30 years after the event in a report that demonstrates sincere bitterness in the face of what had to be called a disaster: things had gone so badly that it all led to the end of the Calchaqui mission, to the return of the war and, finally to the deportation of the ancient neophytes, which, at the time, determined the definite failure of the Jesuits.

Indeed, it was amazing: effectively, Pedro Bohórquez only addressed the diaguitas by means of an interpreter, called Lorenzo Pisapanaco, ${ }^{30}$ whose name indicates that he came from the surroundings of Pomán, since Pisapanaco

\footnotetext{
28Hernando de Torreblanca, Relación Histórica de Calchaquí, Buenos Aires, AGN, 1999. [1696], p. 83. ${ }^{29} \mathrm{AGI}$ Charcas 58, Acta de la segunda junta celebrada el 07-08-1657 en San Juan Bautista de la Ribera (Pomán), AGI, Charcas 121, Nombramiento otorgado a Pedro Bohorques, San Juan Bautista de la Ribera 08-08-1657. ${ }^{30}$ Torreblanca, op. cit., p. 41
} 
was an indigenous group that had been dominated for a long time, which can explain the familiarity he had with Castilian.

However, if we observe more carefully, we realize that Lorenzo was not the only interpreter of that Andean tragicomedy. In the tripartite negotiations between Spanish authorities, Bohórquez and the Indians, the true interpreter voted all over was father Hernando de Torreblanca himself, who attended all the meetings and signed the main documents that gave Bohórquez the power, thus enabling him to officially settle into the Valley. The participation of the missionary in the assemblies that was celebrated for approximately 15 days, from July 30 to August 13, 1657, in the city of Pomán, really took a key part:

Several conferences took place in assemblies [...] and they called me in most of them as interpreter, since, even if there were many "lenguas" [native interpreters], they were not able to understand the topics, because they did not know the Spanish language enough to say what was the proposal, nor they had any knowledge about the countries and populations of Calchaqui. ${ }^{31}$

The good priest, however, omitted a piece of information in his Relación Histórica: that he also had a warrant of Bohórquez and the Indians. Indeed, he participated in the ceremony celebrating the moment when Bohórquez entered this city, followed by hundreds of armed Indians, to meet with the governor and the authorities of Pomán. ${ }^{32}$

\section{Interpreter and military chaplain: the voice of pacification}

One year later, the situation was completely different. It was clear then that Bohórquez was encouraging a "general rebellion" - and that his presence enabled the recomposition of a network of alliances that was impaired by colonial relations. The fact is that, from the jurisdiction of La Rioja - precisely, the dominated valley of Famatina ${ }^{33}$ - up to the reductions of pulares, which had been serving the encomenderos of Salta for a long time, ${ }^{34}$ several arrows of alliance circulated, and they even reached Casabindo and the surroundings of Potosí, ${ }^{35}$ which had not happened in decades. Obviously, Bohórquez ended up looking at the Jesuits suspiciously, until he finally expelled them manu militari

\footnotetext{
${ }^{31}$ Hernando de Torreblanca, Relación Histórica de Calchaquí, Buenos Aires, AGN, 1999. [1696].

32Piossek Prebisch, Pedro Bohórquez, El Inca del Tucumán 1656-1659, Catamarca, Magma, 1999; p. 114 et seq. reproduces several unpublished documents about this arrival. He even names the chiefs who were present in the encounter. Idem, Ibidem, p. 109, nota 181 (es una transcripción de AGI, Charcas, 121).

33“Carta del Cura de Famatina, D. Juan Gedeón de Guzmán, al señor Maestre de campo Juan Gregorio Basan de Pedraza, Alcalde ordinario de los Santos, 20-04-1658", Pablo Pastells, Historia de la Compañía de Jesús en la provincia del Paraguay, Madrid, Victoriano Suárez, 1912, vol. 2, p. 535-536.

${ }^{34}$ Christophe Giudicelli, "La raya de los pulares. Pouvoir colonial et quadrillage de l'espace social dans le Valle de Calchaqui", In: Jimena Paz Obregón Iturra, Luc Capdevila et Nicolas Richard (eds), Les indiens des frontières coloniales. Amérique australe, XVle au XXe siècle, Rennes, PUR, 2011, p. 27-58, y « Calibay o la tempestad. Debate en torno a un documento de la Salta primitiva », Revista Corpus, Vol. 3, n. 1, 2013, http:// ppct.caicyt.gov.ar/index.php/corpus/article/view/2819/2668

${ }^{35}$ Torreblanca, op. cit., p. 45
} 
and ransacked their missions. ${ }^{36}$ He began war operations per se, by attacking the fort of San Bernardo, on the road to Salta, San Miguel de Tucumán, the fort of Andalgalá, sacking from several haciendas and destroying the mines of Acay, on the road that led from the Calchaqui Valley to the Puna plateau. ${ }^{37}$ Once he understood his military offensive had failed, Bohórquez decided to leave the Tucumán, letting Indians and Spaniards, face to face. ${ }^{38}$

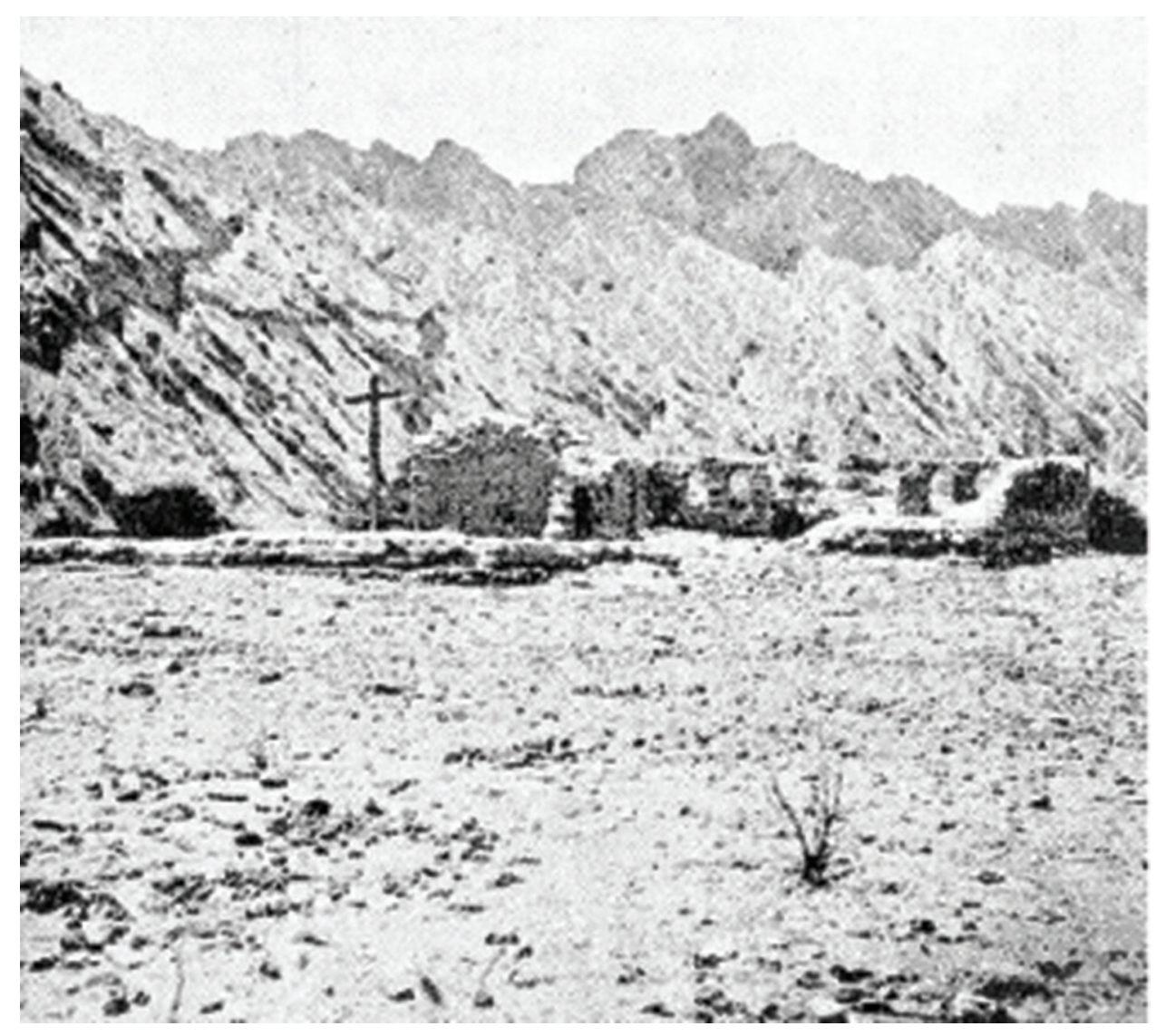

Figure 1. Ruins of the mission of San Carlos de Tucumanahao. ${ }^{39}$

Feeling disabused and actually deprived from their more incaico conversion mirage, the missionaries had no choice but to abandon the Calchaqui valley forever, so that they could be dedicated to another one of their functions: to work as military chaplains in the pacification troops, against their

\footnotetext{
${ }^{36}$ Hernando de Torreblanca, Relación Histórica de Calchaquí, Buenos Aires, AGN, 1999. [1696], p. $49-53$. ${ }^{37}$ Idem, Ibidem, p. 52-53.

${ }^{38} \mathrm{He}$ accepted an official proposal of indult, however, after several situations, he was taken straight to Lima, where he would afterwards be executed in prison. Ana María Lorandi, De quimeras, rebeliones y utopías. La gesta de Pedro Bohorquez, Lima, Pontificia Universidad Católica del Perú, 1997, p. $299-311$.

${ }^{39}$ Picture of Juan Bautista Ambrosetti, "Por el Valle Calchaqui", Anales de la Sociedad Científica, XLIV, Buenos Aires, 1897, p. 289-305. According to several authors, San Carlos de Tucumanahao had been the headquarters of the mission of San Carlos de Samalamao, where the first missionary attempt took place. For the discussion on this argument, see María Teresa Iglesias, Luís Capeletti, Fausto Guerrero, María Victoria Massa, y Liliana Zamagna, "Investigaciones preliminares en el sitio San Carlos (Valle Calchaquí, Salta)", Revista Escuela De Historia, vol. 1, n. 6, 2007.
} 
ex-catechumens. ${ }^{40}$ For this task, the head of the late mission, Eugenio de Sancho, and Hernando de Torreblanca himself, supported the authorities in the offensives that took place in the winter of 1659. The former accompanied the military columns recruited in La Rioja and in Londres, ${ }^{41}$ while Torreblanca was always beside the governor Mercado y Villacorta, who turned him into a key element for pacification. As he had good knowledge of the enemy's tongue, he was the most qualified person to conduct the negotiations, especially to name the surrender conditions imposed by the governor: "My work was continuous, as an interpreter, to persuade them, since I had more abilities with the language to express the inconvenience of their dissipation, if they would not admit peace". ${ }^{42}$

Moreover, since he knew very well the Indians whose surrender he was now demanding, for he had lived among them for more than 15 years, his "cultural" skills made him an excellent military advisor to find conditions that could be acceptable to the defeated, he was able to convince them to surrender:

[...] the governor has given me the favour that no Indian, even a prisoner, would suffer the punishment of having his hair cut off, nor would this person be beaten or mutilated; and so he gave it to me and his word was kept. ${ }^{43}$

In other words, the former missionary became an essential element in the pacification forces. He played a key role in the crucial negotiation that led the calchaquies of Tolombón and Paciocas, who had always had a central role in the previous wars, to change alliances under military pressure, and to fight from then as "friendly Indians" against their neighbors the Quilmes among the Tucuman troops. ${ }^{44} \mathrm{He}$ also participated actively at the end of the first campaign in identifying the defeated groups and organizing their deportation.

Between 1660 and 1664, governor Mercado y Villacorta had to leave the administration of the Tucumán to take over the one of the Río de la Plata. Therefore, the pacification process that he had begun was interrupted. At the end of his term in Buenos Aires, he returned to his former position, with the explicit mission of finishing the work he had begun five years earlier, that is, removing all of the rebel Indians, especially the ones from Quilmes and the Yocavil Valley. ${ }^{45}$ Among his first measures to prepare this second campaign, Mercado reassigned the creole and translator Jesuit that had brought so many positive results:

\footnotetext{
$\overline{40}$ In this case, it is likely that they were so careful to participate in the military operations because they were aware of their responsibility in this situation, however, this type of participation was constant in all of the pacification operations in the "frontiers" of Spanish America. See, for instance, Christophe Giudicelli "Indios amigos y normalización colonial en las fronteras americanas de la Monarquía Católica (Tucumán, Nueva Vizcaya, S. XVI-XVII)", In: José Javier Ruiz Ibáñez (Coord.), Las milicias del rey de España. Sociedad, política e identidad en las Monarquías ibéricas, Madrid, FCE, 2008, p. 349-377.

${ }^{41}$ Hernando de Torreblanca, Relación Histórica de Calchaquí, Buenos Aires, AGN, 1999. [1696], op. cit., p. 66.

${ }^{42}$ Idem, Ibidem, p. 71.

${ }^{43} / \mathrm{dem}$, Ibidem

44/dem, Ibidem, p. 70

${ }^{45}$ Roxana Boixadós, "El fin de las guerras calchaquíes. La desnaturalización de la nación yocavil a La Rioja (1667)", Corpus n. 1, 2011 (en línea). Christophe Giudicelli, "De la déportation à l'invisibilisation: la "dénaturalisation" des Indiens Calchaquís (Nord-ouest argentin), XVIle-XXle siècle", in dossier "relocalisation et résilience autochtone”, Recherches Amérindiennes au Québec 41(2-3), 2011.
} 
He prepared himself (Alonso de Mercado) in the Port, he emitted the provision order, that for the campaign he had to make for the conquest, the Provincial Society should provide two priests for as long as necessary, and one of them was P. Hernando de Torreblanca, since he had worked there for many years, and because he accompanied the period after rebellion: being a translator and knowing about the Indians. ${ }^{46}$

In this case, his particular skills - "being a translator and knowing about the Indians" - would not only be useful for peace negotiations, but also to take over a position that had been assigned to him in the chain of power. He was in charge of translating the orders and other military instructions into kakán, which were transmitted by the governor to the contingents of friendly Indians of Tolombón and Paciocas in the campaigns against their former allies. The governor declared that Torreblanca was the only one who could do that:

There was always something to do with the Indians because there was no other "lengua" [interpreter] that, in the idiom of their language, made them understand what was intended, and the governor wanted them to do. ${ }^{47}$

The command of the from now on "calchaqui friends'” language, achieved by this missionary definitely changed what is supposed to have been his first calling: even if he still performed spiritual functions in several colleges the Society of Jesus ruled in the province,${ }^{48}$ he also kept devoting time and energy to surveillance and pacification tasks when he was mobilized by the authorities. The argument he supports in the Relación chronicle is that nobody could speak kakán as he did. And since the calchaquies groups who had been reinstalled in the Choromoros Valley ${ }^{49}$ had become the main auxiliary militia against the Chaco Indians,, on the more and more tumultuous eastern fringes of the Tucumán,, there was no way he could refuse to accompany them in their expeditions, so that the chain of power could not be interrupted:

Being in Salta the mocobí Indian raided the fort of Esteco, and it was necessary to provide help in that location; and all the hurry accompanying this faction; and since the ones who immediately helped were the Calchaquis, he always had to be there, busy to make them understand what was ordered, and outside of their country there was nobody who could understand them. ${ }^{50}$

One important point worth mentioning here is: even if the participation of the priests in the fiercest military campaigns was part of their attributions, not only in the American scenario - in this case, they explicitly recognize to

\footnotetext{
${ }^{46}$ Hernando de Torreblanca, Relación Histórica de Calchaquí, Buenos Aires, AGN, 1999. [1696], p. 85. ${ }^{47}$ Idem, Ibidem, p. 86.

${ }^{48} \mathrm{He}$ was the dean of the School of Salta, and then the military campaigns. ARSI, Paraquaria 4-1, F $217 \mathrm{~V}$. ${ }^{49}$ Cristina López de Albornoz, "Las desnaturalizaciones Calchaquíes y sus efectos en las poblaciones trasladadas al Valle de Choromoros", Anuario de estudios americanos, Tomo XLVII, 1990, p. 29-42. ${ }^{50}$ Hernando de Torreblanca, op. cit., p. 71 y 85-86.
} 
"imitate the Castrensian chaplainsy of Flandres" ${ }^{51}$ What is surprising and interesting for us in this very case is that the task assigned for father Torreblanca had a more practical - linguistic - than spiritual nature, and also that this task was assigned to him simply because there was no other option. In other words, what is rather astonishing here is the fact that the governor had at his disposal for his military campaigns no one but an interpreter wearing a cassock and with considerable age. ${ }^{52}$ Or that he had not found anyone, for instance, to escort the thousands of vanquished Quilmes Indians who were deported to the port of Buenos Aires, more precisely, to the reduction of Exaltação de Santa Cruz dos Quilmes, whose foundation is the origin of the present city of Quilmes. ${ }^{53}$ This last issue deeply concerned Torreblanca, who had applied in vain for this position: "the Indians were taken more than 200 leagues away and taken to reductions with a clergyman who could not even understand their language". ${ }^{54}$

Even though considering that, at the end of his life, Torreblanca was influenced by the will to counterbalance his embarrassing role in the ruin of the Calchaqui mission, by emphasizing his brilliant capacity to learn Amerindian languages, one can conclude that there was simply nobody, at that time, able to work as an interpreter from kakán to Castilian, and vice-versa. Another factor that could confirm this hypothesis: it is known that Mercado y Villacorta "did not like the Society very much", and therefore it is possible to assume that Torreblanca's selection was made mainly due to practical considerations. However, this almost automatically leads us to another question: how was it possible that nobody, or hardly anybody, had been able to speak this language apart from the natural-born speakers, that is, the diaguitas themselves?

\section{The kakán, "general language"}

At first, a reflection would lead us to think that this was not such a comprehensive and a bit marginal language. However, this hypothesis should be immediately ruled out for two reasons. The first one deals with the inmediate context: the extent of the deportations we just mentioned earlier - at least 12,000 people, according to the calculations of the governor ${ }^{55}$ - turns the kakán-speaking population into the most important one

\footnotetext{
51"Carta Anua of the Provincial Simon de Ojeda, years 1658-1680, In: Hernando de Torreblanca, Relación Histórica de Calchaquí, Buenos Aires, AGN, 1999. [1696], p. 132: "[..] y así fueron despachados para este fin tres de los misioneros que habían estado entre los calchaquíes, imitándose la capellanía castrense de Flandes”. ${ }^{52} \mathrm{ARSI}$, Paraquaria 4-1, F. 117 et seq, according to the trienal catalog $\mathrm{f} 1631$, there were more than 50 years to the second expatriation campaign, since he was born on September 13, 1613.

${ }^{53}$ Miguel Angel Palermo y Roxana Boixadós, "Transformaciones en una comunidad desnaturalizada: los Quilmes, del Valle Calchaquí a Buenos Aires”, Anuario del Instituto de Estudios Históricos y Sociales, v. 6, 1991, p. 13-42; Florencia Carlón, “La reducción “Exaltación de la Cruz de los indios Quilmes”: un caso de relocalización étnica en Pampa a fines del siglo XVII", Mundo agrario, vol. 8, n. 15, 2007 (en línea).

${ }^{54}$ Hernando de Torreblanca, op. cit., p. 111.

${ }^{55}$ Antonio Larrouy, Documentos del Archivo de Indias para la historia del Tucumán, vol.1 Santuario de Señora del Valle, T.l, Buenos Aires, 1923, p. 276.
} 
in the region, in a period in which Indigenous groups of the Tucumán's controlled areas had reached their lowest demographic point. The second reason is simply that evidences and testimonies show without the shadow of a doubt kakán was, on the contrary, an extremely comprehensive language when Spanish colonizers arrived, undoubtedly spoken outside its main area, that is, the Interandean corridor of Tucumán and part of the Tucumano-Santiagueña plain. In 1582, Pedro Sotelo Narváez, in a report to judge Cepeda, president of the Charcas Audience, presents the language as a vehicular one: [...] they speak a language called diaguita, which is general among them, however, there are four other languages called tonocoté, indama, sanavirona and lule". ${ }^{56}$

So, the fact that a Spaniard familiar with the reality of the Peru vice-kingdom mentions the "general language" is all but insignificant. It really brings to the fore the important status and role of this tongue. However, some could not rely on the linguistic sensitivity of a mere swordsman from this distant province all the more so since Tucumán colonists were rather known for their brutality than for their love for Art and Humanities. It would be more unlikely to question the word of the first missionary who was sent there by the Society for the evangelization of the Tucumán Indians. Even less knowing this missionary was one of Peru's pioneer Jesuits, Alonso de Barzana, disciple of Juan de Ávila, who arrived at Lima on the same boat as viceroy Toledo in 1569, veteran of the first Society's "doctrinas", Santiago del Cercado, Huarochirí and Juli. This tillustrious jesuit is also know for having written first ever grammar and catechism in quechua and aymara, the redaction of which was decided during the first provincial congregation of January, $1576 .{ }^{57}$

Barzana was among the most remarkable linguists of the Society, and he apparently dominated the main indigenous languages of current Bolivia, which he practiced not only in his missionary function. Actually, he also had taught them as a titular professor in the diocesan cathedra of quechua, aymara and puquina in Potosí since 1583, a decentralized course of the University of Lima, instituted three years earlier, in $1580 .^{58}$

In 1593, while announcing the composition of a vocabulary in five languages, written with his partner, Pedro de Añasco, whose particularity was to be a mestizo, born in Chachapoyas, he described the kakán as follows:

[...] the third language of this vocabulary is even more general than this one [tocotoné] because it is spoken by most people who

\footnotetext{
56Roberto Levillier, Nueva crónica de la conquista del Tucumán, v. 3, p. 324-332.

${ }^{57}$ Charles O'Neil, Joaquín M. Domínguez, Diccionario histórico de la Compañía de Jesús, Institum historicum, SI \& Universidad Pontificia Comillas, Madrid, 2001, p. 362-363.

${ }^{58} \mathrm{~A}$ Royal Decree so that the cathedras of the University of Kings establishes a general language of the Indians, so that the priests can administer them and be aware of this language. 23-09-1580 Pablo Pastells, Historia de la Compañía de Jesús de la provincia del Paraguay, Madrid, 1912, p. 20-22 NB: 5-10-1580: "another one from 5-10-1580: "para que la cátedra de lengua general de los indios que se lee en la universidad de los Reyes se instituya en todas las partes de las Indias donde hay Audiencias y Cancillerías Reales (para que los sacerdotes que salgan a las doctrinas hayan cursado en ella)".
} 
serve Santiago and all of the Catamarca valley, as well as the hundred of people conquered by the governor in Londres and in all of the Calchaquí valley, which were conquered in the last years. ${ }^{59}$

In the following year, he would confirm the general extension of this language:

The most general languages of the Indians in this land are caca, tonocoté, sanavirona. Caca is used for all of the diaguitas and all of the Calchaquí and Catamarca valleys, as well as by most of Nueva Rioja, and practically all of the peoples who serve Santiago, as well as the peoples of the del Estero river, and even many others who live in the mountain. This language is expecting the diligence of our workers, because there are thousands of infidels we could not reach until now. Art and vocabulary are made out of this language. [...] Whoever is lucky enough to be the diaguita apostle, and know the caca language well, will walk through the peoples of Nueva Rioja and the Famatina and Calchaquí valleys, as well as Catamarca, and all of these nations that I haven't seen, this one will be able to give account $[\ldots]$ of how many peoples there are $[\ldots] .^{60}$

It is probably clear enough at this point that, for Barzana and his immediate contemporaries, it was an extremely comprehensive language, and to qualify it as 'general' was like equating it to the quéchua language in Perú, to the guarani in Paraguai or Rio de la Plata, or to the náhuatl, in Central Mexico. Therefore, it would have been logical — and practical - to establish some more or less institutionalized interpretation mechanisms,. It should be observed that, on the contrary, the passage from a language into another did not only stop being a problem during the entire considered period, but it was even slowly abandoned due to the use of other communication tongues, especially quéchua, which began to be the preferential language of communication with Indigenous populations, in work relations, in justice and administration. Our hypothesis is that since kakán was mainly the enemy's language, its use was progressively restricted to two specialized fields - with different and complementary modalities though — both dealing with the subjugation program and the social transformation that was being implemented by colonial power: surveillance and military control, on the one hand, and the mission network, on the other.

\section{The quéchua, "língua franca"}

Since the very begining of the Tucumán province, due to the immediate geographic origin - Peruvian - of most colonists and their indigenous servants, quéchua was used as the second colonial tongue, before slowly becoming the first communication language with "domestic" Indians, who had to learn it when

\footnotetext{
${ }^{59 “}$ “Carta de Alonso de Barzana al Provincial, 1593, 20-12, In: "Anua de la provincia del Perú", Monumenta Peruana, T.V., Roma, Institutum Historicum Societati lesu, 1970, p. 383, et seq.

60"Carta del padre Alonco de Barçana al p. Juan Sebastián, provincial 1594, 08-09 (desde Asunción)", Monumenta Peruana, T.V., op. cit., p. 568-580, et seq.
} 
they did not know it yet. As it is known, there were linguistic islands of quéchua in some parts of the Argentinian Northwest, especially the region of Santiago del Estero. It is also possible that, at some point, due to the past presence of mitmaquna settled by the Incas in the region, some groups had some knowledge of the imperial language, besides their own. ${ }^{61}$ However, this does not seem to have been the case of kakán-speaking populations , who occupied this apparently conflict-ridden frontier of prehispanic Tawantinsuyu. For these diaguitas populations, the generalization of quéchua from the late $16^{\text {th }}$ century on, clearly has a colonial origin, and its consequence is of much interest to us: the communication between the different colonial instances and the Indians slowly went through a double linguistic filter: kakán-quéchua-spanish.

There are some cases, especially at the beginning of the period, of simple interpretations. For instance, when the encomendero Juan de Abreu, took possession of the Indians of Amimaná village, in 1592: when appearing before the authorities [...] "an Indian named ynga and an Indian named Panizay, whose declarations were recorded [...] by me the present scrivener (called Pedro Hernández) who know the diaguita language very well [...]". Later on, the scrivener added just in case that "the refered Indian understood me well".62

Even so, the declarations of the Indians went sometimes through a longer itinerary. In 1622, when the bishop of Tucumán, Julián de Cortázar, visited the Calchaquies valleys, for instance, all declarations were translated "by Diego Laines, indio ladino", that is, in that case - which was very common - who spoke quéchua, who was "ladino in the general language of the inga": "which Diego Laines interpreter said in the general language of the ynga, what were saying the Indians, a language he understands and I speak".63

That is, the declarations of the calchaquies, who expressed themselves in kakán, were translated by the ladino Diego Laines to quéchua, and soon were translated to Castilian by the scrivener, called Juan de Higueras. ${ }^{64}$ In the Tucumán and in the rest of the vice-kingdom of Peru then, everything was done so that the quéchua could be used as a lingua franca. Even voluntarist measures were taken to extend its use among the Indians and Spanish-creoles. The synod of 1602 explicitly predicted, for instance, that priests should teach it in quéchua "[...] because most of the Indians pray and are becoming ladinos in that language". ${ }^{\prime 5}$ As for them, local elite pressurized so that top authorities would fall back on to someone with some experience in America - not to say a creole

\footnotetext{
${ }^{6}$ Ana María Lorandi, "Evidencia en torno a los mitmaqkuna incaicos en el N.O. argentino", Anthropologica, n. 9, diciembre de 1991, p. 213-243.

${ }^{62}$ AGN, 1596, 14-09, "Posesión de los indios encomienda del pueblo de Amimaná a Juan de Abreu”.

63“Expediente de la visita que hizo el obispo de Tucumán, Doctor Julián Cortázar en el Valle Calchaquî", In: Roberto Levillier (ed.), Papeles eclesiásticos del Tucumán, Madrid, ed. De Juan Pueyo, 1926, vol. 1, p. 315.

${ }^{64} \mathrm{AHPC}$, Escr. 1a, leg. 15, exp. 12, "Martin de Mojica contra Alonso Martin de Zorita sobre indios 1602". Several similar cases were found in the Tucumán, and not only in diaguita lands, for example, the possession of the encomienda of Martín de Mojica, in the jurisdiction of Córdoba, also took place with the "natural language", there was "un muchacho de su servicio que conoce la lengua general del Piru que yo conozco".

${ }^{65}$ Quoted by Estela Noli, “Indios ladinos del Tucumán colonial: los carpinteros de Marapa”, Andes, n. 12, 2001, p. 141.
} 
- and, for starters, who knew the general language. In this sense, the cabildo of San Miguel de Tucumán asked, in 1613:

"[...] that the governor knows the general language of the ynga, which is understood by many Indians in these provinces, especially the ones who work in villages and houses of the Spanish. ${ }^{66}$

If direct communications were still relatively limited, the ladinization (into quechua) of the Indians who were incorporated to the colonial sphere was progressivelly imposed. There are many examples. Let us mention a borderline case, another ceremony in which two colonists took possession of Indians - probably "pieces" 67 - during the foundation, in the heart of the Calchaqui valley, of the short-lived fort of Nuestra Señora de Guadalupe, in 1635. It took place "[...] in the general language of Peru, which is understood and spoken by the mentioned Indians [...]". ${ }^{\prime 8}$ The two prisoners were: "Luís Guallanchay, cacique principal of the Guatungasta village, and Diego, ladino from the Fiambala village".

\section{If direct communications were still relatively limited, the ladinization (into quechua) of the Indians who were incorporated to the colonial sphere}

As in the already mentioned case of Lorenzo Pisapanaco, they were encomiendas diaguitas, from the jurisdiction of La Rioja, who had fled into the rebel calchaqui area taking advantage of the "Great Rebellion", which would explain their ladino condition. It is possible to compare this situation with the one of the pulares, another separate segment of the initial generic group, called diaguita by the Spanish-creoles, as a consequence of their subjugation and early incorporation in the different economic and "civilization" devices imposed by the rules of colonial coexistence. The fact that some Indians adopted quéchua was, at times, a result of the regular contact with the Spanish, much more than an evidence of an ancient incorporation to the Inca world, which would have imposed the empire language in those far away and conflicting frontiers. These contacts were rather common during the mita periods, which led them to work in the cities of the province, in the lands of their encomendero, and at times, even to ride mule trains until the center of the Charcas Audience. The synchronic analysis of the command of the "general Inca language" by kakán-speaking

\footnotetext{
${ }^{66}$ Levillier, op. cit. p. 100-103, subrayado nuestro.

${ }^{67}$ That is, Indians arrested in "fair war" and deposited, for a specific amount of time to the services of a Spanish man. About that practice, see Gaston Doucet, "Sobre cautivos de guerra y esclavos indios en el Tucumán", Revista de historia del derecho, n. 16, 1988, p. 59-152.

${ }^{6}$ Serviços do capitão don Gregorio de Luna y Cárdenas, AHPC-Escribanía II-4 n. 24; Aníbal Montes, Encomiendas de indios diaguitas documentadas en el archivo histórico de Córdoba, Córdoba, 1986, p. 10.
} 
groups, who were sometimes relatives, but separated by what one can only call the 'war frontier,' clearly demonstrates the determining character of the colonial relationship in this learning process ${ }^{69}$ Likewise, studies about indigenous groups on the western side of the Aconquija mountain, which had been long controlled by encomenderos from San Miguel de Tucumán, demonstrate the progress of quéchua in groups that originally spoke kakán. This is particularly obvious after the the 1659-1665 deportations and the reorganization of groups withdrawn from the valiserrana area in the same region.

The visit of priest Vergudo Garnica, in 1685 clearly proves that their knowledge of quéchua was notoriously inferior, even if they had the same mother language. ${ }^{70}$ A study by Estela Noli about the Marapa village people , who directly depended on San Miguel de Tucumán, also shows the abyss separating the inhabitants of that village, all of whom were ladinos in quéchua, from the newly-expatriated group, for whom it was difficult to defend in a situation in which the use of quéchua was strategic. ${ }^{71}$

\section{The kakán, enemy's language/spealking the enemy's language}

If the colonial expansion of quéchua in the Tucumán is part of a general process, it is still to be understood why kakán, which was a vehicular regional language at the time the Spanish-creoles arrived, ended up marginalized and practically excluded from colonial communications, so much that, in the mid- $17^{\text {th }}$ century, the only ones who could speak it, besides the Indians, were the few missionaries who lived among them. The explanation undoubtedly points out to the symbolic status of this language in relation to the position of its speakers in the surveillance economy of the province. It had been circumscribed as the enemy's language and was geographically identified with the resistant calchaqui enclave, at least since the first rebellion of 1562, which devastated all of the cities founded in the valiserrana area. What dramatically increased suspicions was the fate of Córdoba of Calchaquí's inhabitants: they were slaughtered, except for the children and women, who were then captured and spread among the Indians. Some of those children were recognized many years later, among the "pieces"

\footnotetext{
${ }^{69}$ Rodolfo Cruz studies this matter between Tafies and Amaichas, "La "construcción" de identidades étnicas en el Tucumán colonial: Ios amaichas y los tafies en el debate sobre su "verdadera" estructura étnica", In: Ana María Lorandi (comp.), El Tucumán colonial y Charcas, Buenos Aires, FFyL - UBA, 1997, T. II, p. 253-282.

${ }^{70}$ Larrouy, Documentos del Archivo de Indias para la historia del Tucumán, vol.1 Santuario de Señora del Valle, T.I, Buenos Aires, 1923, p. 360, et seq.

${ }^{71}$ Estela Noli, "Indios ladinos del Tucumán colonial: Ios carpinteros de Marapa", op. cit.. Quechua extends with much eloquence to the main sectors of activity, and it ends up contaminating the daily Spanish, after naming essential categories of economy. The report of father Juan Ximénez about the abuse of pobleros das encomiendas of London denounces, for instance, that: "Todos los días de la semana el poblero y camayo de cualquiera pueblo, al amanecer hace juntar a los curacas y fiscales los dichos indios e indias" para repartirles un guarço de lana para hila (cited in Laura Quiroga, "Las granjerías de la tierra: actores y escenarios del conflicto colonial en el valle de Londres (gobernación del Tucumán, 1607-1611)", Surandino Monográfico, segunda sección del Prohal Monográfico, vol. 2, n. 2, 2012 (en línea).
} 
led with halters, after the military expeditions, totally indianized. They had lost their mother tongue, which strongly scared the local colonists. ${ }^{72}$

Speaking kakán could even be considered a sign of infidelity, when its practice overstepped the restricted mark of colonial relations. The most famous case - little documented though - is the scandal caused by Juan Baptista Muñoz, son of one of the founders of Londres and San Miguel de Tucumán, a rich and powerful man, benefactor of the Society of Jesus ${ }^{73}$ Juan Baptista Bernio. Muñoz had sheltered into the mountains prefering to escape along with his Indigenous concubines to war lands rather than live with his legitimate wife, according to the Christian moral principles, as it was demanded by the then governor, Juan Ramírez de Velasco.

In a late 1586 report, the governor established that:

[...] the city council, neighbors and other people in the city of San Miguel de Tucumán of this administration warned me about a boy named Juan Baptista Muñoz, son of Juan Baptista Bernio, who, with no apparent cause, left this city and mingled with the enemy Indians, and is strengthened with them [...] he really wants to do bad things and, as a ladino in the natural languages of this government he wants to cause damage with them to the Spaniards in the city. ${ }^{74}$

As it can be seen, speaking the enemy's language seemed to be an aggravating factor, and put this individual in an open rebellious situation, similar to the one of the "enemy Indians", that is to say, at that time the whole kakán-speaking population who lived in the high valleys of the Tucumán, ${ }^{75}$ where Spanish prisoners - and lovers - were at risk of losing their Castilian.

Our hypothesis is that, beyond scarce administrative relationships , the management of the interlocution between calchaquies and Spanish-creoles had been rapidly limited to pacification and submission policy, reserved to two kinds of experts: military and religious men, for different but partly converging reasons all the more so since here like in every single conquest area, the missionaries arrived within the troops, and the missions installed in the military campaigns' wake. In our case, the first Jesuit sent down from Peru to meet kakán-speaking Indians, was the aforementioned Alonso de Barzana, and

\footnotetext{
${ }^{72}$ Christophe Giudicelli, "El conquistador y su sombra. Silencios en la conquista del Tucumán (siglo XVI)", In: Christophe Giudicelli, Gilles Havard y Salvador Bernabéu Albert (eds), La indianización. Cautivos, renegados, "hommes libres" y misioneros en los confines de América (Siglos XVI-XIX), Madrid, Doce Calles, 2013, p. 137-160. ${ }^{73} \mathrm{AHT}$, protocolos, vol. 1, FS 1-2vta, "Don Juan Bautista Bernio alguacil del Santo Oficio de la Inquisición, hace donación a favor de la Compañía de Jesús de un solar de tierras que cae a la parte del río de la ciudad”, San Miguel de Tucumán, 9-12-1588.

74“Comisión dada por el gobernador Don Juan Ramírez de Velasco al capitán Hernán Mexia Miraval para que fuese a prender a Juan Bautista Muñoz 24-1-1586", In: Roberto Levillier, Probanzas de méritos y servicios de los conquistadores, Madrid, Sucesores de Rivadeneyra, vol. 2, 1919-1920, p. 602. Our mark.

${ }^{75}$ Besides San Miguel, the only city that had been founded was Salta, in 1582, however, according to Rámirez de Velasco, "aunque ha cinco años que se pobló, no le sirve indio, y se sustenta con grandísimo trabajo, por no haber más de un fuerte en que están 30 o 35 soldados, con solo la esperanza de que se ha de salir á hacer la guerra, sin llevar salario ni gaje de S. M., el teniente y los soldados, á cuya causa pasan mucha necesidad", "Carta del gobernador Don Juan Ramírez de Velasco al virrey del Perú, conde del Villar, O4-061587, In: Roberto Levillier, Gobernación del Tucumán, Papeles de gobernadores en el siglo XVI, vol. 2, Madrid, Juan Pueyo, 1920, p. 209-213.
} 
he did not do is first as a missionary, but as a chaplain of the troops sent from Salta for a particularly difficult campaign in the valleys, which lasted for several months. ${ }^{76}$ It was also under the instance of the civil and ecclesiastic authorities, and under the protection of the soldiers in this same city, that the Society of Jesus could develop its missionary work with the Indians, firstly with sporadic missions, and afterwards, through a permanent presence into the valley, in two periods: between 1617 and $1624^{77}$ and in 1643-1658.

\section{Linguistic highs and lows of evangelization}

Missionaries had so to speak both technical and professional interest in acquiring the commad of kakán: they had to preach the Indians the Good News and had to convince them to embrace life according to the principles of the "Christian policy".

As we have seen, the linguistic work of the missionaries in diaguita lands seems to correspond to the excellence so much mentioned by the historians of the Company. The famous father Barzana, well known as the apostle of the Tucumán, and his partner, Pedro de Añasco, had written, since the first years, a catechism and a vocabulary in order to make easier the missionary work, and these efforts seem to have taken some effect as soon as in 1594:

One single priest started to marry, confess, catechize in it; even if he was a beginner, he baptized many people and married and confessed many others who, in their whole life, never got to know what it meant to confess. ${ }^{78}$

In these years, the practice was guided in Tucumán, as in all of the jesuit misssion fronts, towards the multitudinous administration of sacraments, so that the priests did not worry too much wether if they actually understood confessions, or if the Indians could appreciate the subtleties of the mystery of the Eucharist. ${ }^{79}$ Nevertheless, despite these promising principles, the progress of the next missionaries in kakán was to be fairly limited.

The 1609 Carta Anua mentioned that "father Horacio [Morelli] is progressing quite well with the language and very carefully, he catechizes and speaks

\footnotetext{
76“Carta del gobernador Juan Ramírez de Velasco a S.M., 13-03-1588”, In: Roberto Levillier, Gobernación del Tucumán, Papeles de gobernadores en el siglo XVI, vol. 2, Madrid, Juan Pueyo, 1920, p. 235-239.

${ }^{77}$ María Florencia Amigó proposed the year of 1622 for the first abandonment of the Jesuit doctrines., El desafío de Calchaquí. Un puñado de jesuitas entre un mar de indios. La intervención de la Compañía de Jesús en el Valle Calchaquí (siglos XVI-XVII). Tesis (Licenciatura en Ciencias Antropológicas) - Facultad de Filosofía y Letras, Universidad de Buenos Aires, 2000. A report by the provincial Pedro de Oñate, from 1623, states that the residence of Calchaquí "tiene cinco padres y un hermano. Dales su Mgtd para su sustento 1,200 pesos de renta con que apenas se puede sustentar el dicho numero. No tienen iglesias ni ornamentos bastantes ni alhajas sino mucha pobreza". ARSI, Paraquaria 4-1, F. 89 v. Another adjunct report to the trienal catalogo f 1626 by provincial Nicolás Mastrilli Durán informs that the school of Salta is in charge of "misiones de Calchaquí, de las que les hemos salido por falta de sustento" (ARSI, Paraquaria 4-1, F 110 f). Out of the document mentioned in note 12, it is posible to infer that the permanent mission disappeared probably in 1624.

78“Carta do padre Alonco de Barçana ao p. Juan Sebastián, provincial 1594, 08-09 (de Assunção)", Monumenta Peruana, T.V., Roma, institutum historicum Societati lesu, 1970, T.V., p. 568-580, et seq.

${ }^{79}$ The multitudinous baptisms were performed at the same time in the new province of Tepehuanes, to the North of New Spain. See the reports by father Jerónimo in the Cartas Anuas of 1596 and 1597. Vicente García Torres (ed.), Documentos para la historia de México, México, 1854-1857, 3 vol.
} 
using it [... $]{ }^{80}$ However, even though the Society had settled in two fixed residencies between 1617 and 1624, the 1626-1627 Carta Anua still mentions the learning process of the missionaries: "[...] it is applied to learn the chaca language and to recall by heart a brief catechism we have done so that all of us can preach [...]". ${ }^{\prime 1}$ Ten years later, in the mid-1630s, the level seems to have gotten worse. Missionaries do not even try to preach or decode confessions; they cannot even communicate, "[...] and sometimes it is necessary to use one or two the interpreters of different languages, because the Fathers do not understand their tongue, to instruct, them and made them able to confess". ${ }^{22}$

Even the apostolic message publicized by the Jesuit chaplains during "pacification" campaigns had to go through one or several interpreters:

[the priests] left them well instructed in the matters of faith, using good interpreters, since their language was too complicated, and because many of them could not understand the general one, usually spoken by the priests. ${ }^{83}$

The question that could be asked at this point is why the Jesuits, light-years away from their fame as brillant experts in learning Indigenous tongues ${ }^{84}$ (and not only in the New World), left such a poor impression in Tucuman. The excuse that kakán was hard-learning is not convincing enough, "a language ([...)] that was strangely barbarian, with a harsh pronunciation". ${ }^{85}$ The explanation is clearly to be find elsewhere. It leads at least to two factors: one the one hand the delicate position of the Society in the early decades of $17^{\text {th }}$ century, due to its radical opposition to "personal service", and on the other hand the already mentioned ideological situation of kakán.

Even the apostolic message publicized by the
Jesuit chaplains during "pacification" campaigns
had to go through one or several interpreters

As to the first factor, it is clear that with their position against "personal service" the Jesuits of the recently founded province of Paraguay did not earn the immensurable love of the first ones to be interested in its prepetuation, that is, the encomenderos, who held the reality of the power in the Tucumán. The Jesuits criticized the "personal service", generalized and regularized in the

\footnotetext{
80 Paraquaria, 8, ff 30f-32 f, reproduced in "Documentos para la historia de Argentina”, Buenos Aires, Instituto de Investigaciones Históricas Dr. Emilio Ravignani, FFyL, UBA, 1927-1929, T. 19, p. 75-77.

81“Documentos para la historia de Argentina”, Idem, T. XX, p. 178-183.

${ }^{82}$ Anua de 1635-37, "Documentos para la historia de Argentina”, T. 20, p. 400-415

${ }^{83}$ Anua de 1632-1634, Cartas Anuas de la provincia jesuitica del Paraguay. Academia Nacional de la Historia, Buenos Aires, 1990, p. 53.

${ }^{84} \mathrm{~A}$ broadly masked reputation, if not magnified in many regions. To the North of Mexico, see Bernd Hausberger,

"Política y cambios lingüísticos en el noroeste jesuítico de la Nueva España”, Relaciones, n. 78, 1999, p. 59-77.

${ }^{85}$ Anua de 1632-1634, Cartas Anuas de la provincia jesuítica del Paraguay, op. cit., p. 72-73.
} 
Tucumán, since the rules established in 1576 by governor Gonzalo de Abréu ${ }^{86}$, and they did so even before the promulgation of the new ones, by the inspector and judge of the Charcas Audience, Francisco de Alfaro. The extremely harsh reports presented in 1609 by the theologian of the Society, Juan Pérez de Menacho, were signed by the Tucumán missionaries: Horacio Morelli, Luís de Hoyos and Juan Darío. ${ }^{87}$ The Cartas Anuas written in the 1610 s by father Diego de Torres Bollo condemn, with harsh terms, the greed and cruelty of the encomenderos, ${ }^{88}$ which turned the local elites against them. Within a few years, their staying in the permanent Calchaqui missions became impossible, and they finally had to abandon them in 1624, after a terrible report by bishop Julián de Cortázar, who finally discredited the missionaries' work, joining the position of the encomenderos. ${ }^{89}$

We believe that the second factor, however, was even more important to explain the scarce progress of Jesuits among the calchaquies and their difficulty to learn their tongue. Since it was the language of the enemy within, geographically and politically confined, the missionaries seem to have devoted themselves - or been limited - to their political tasks. This attention was explicit from the very beginning: they had been called up "to pacify and reduce the Indians" ${ }^{\prime 90}$ After the almost 15 years of the Great Rebellion, it was necessary to start from scratch. Therefore, they chose to privilege the reinstallation of the permanent missions in the valliserrana region, sending four priests to the old San Carlos and Santa Maria doctrinas. Though the objective also approached religious aspects, supposedly, it should be emphasized that the initiative was once again taken by the civil authorities and by the bishop of Tucumán, Friar Alonso Maldonado, considering mainly more temporal restlessness of surveillance and a softer pacification process. What surprised the bishop - and one can understand him — was the lack of preparation of the Jesuits, especially as regards language matters : “[...] when the Society of Jesus was asked to return into the valley, they had nobody who could understand the language, which is pretty singular".91

Therefore, new workers had to be formed in a hurry. Now, nothing better for that than another sort of expert: the appointed priests were first sent to the fort of El Pantano, a kind of militarized mega-reduction to where those of the diaguitas Indians considered more guilty had been deported and concentrated in the late $1630 \mathrm{~s}^{92}$ There, for their learning and missionary work,

\footnotetext{
${ }^{86}$ The text of the rules is reproduced in Levillier, Gobernación del Tucumán, Papeles de gobernadores en el siglo XVI, vol. 2, Madrid, Juan Pueyo, 1920, T. 2, p. 32-45.

${ }^{87}$ AGN, Fondo Biblioteca Nacional, n. 5621 (leg. 840), “Pareceres sobre las principales ordenanzas del gobernador del Tucumán Gonzalo de Abreu, relativas al servicio personal de los indios de aquella gobernación".

${ }^{88}$ Anua de 1613, Documentos para la historia Argentina, T. 19, Buenos Aires, Instituto de Investigaciones Históricas Dr. Emilio Ravignani, FFyL, UBA, 1927-1929, p. 197.

89“Expediente da visita do bispo de Tucumán, Doctor Julián Cortázar ao Vale de Calchaquí, 02-10-1622, 11-1622”, Roberto Levillier, (ed.), Papeles eclesiásticos del Tucumán, Madrid, ed. De Juan Pueyo, 1926, vol. 1, p. 308-323. ${ }^{90}$ Anua de 1624, Documentos para la historia Argentina, T. 19, p. 75.

${ }^{91}$ Carta del obispo Fray Melchor de Maldonado, 13-09-1658, In: Larrouy, Documentos del Archivo de Indias para la historia del Tucumán, vol. 1 Santuario de Señora del Valle, T.I, Buenos Aires, 1923, p. 202.

${ }^{92}$ Ana María Lorandi y Sara Sosa Miatello, “El precio de la libertad. Desnaturalización y traslados de indios rebeldes en el siglo XVII", Memoria Americana, vol. 1, n. 1, 1991, p. 7-28.
} 
the apprentice missionaries could count on the rough knowledge, from 1639 to 1643 , of a character who knew the language of those war prisoners very well, for obvious reasons. It was Antonio Calderón, the one who had been endowed with the military charge of the fort. ${ }^{93}$ Hernando de Torreblanca, who was not yet the great interpreter he would proudly claim to be later on, made a sincere tribute to his master in the Relación:

In this time we had a great translator called Antonio Calderón, as our interpreter, check the calchaqui vocabulary, and compare it to the words of the language spoken here, which varies a lot in pronunciation, even if in substance they are similar. ${ }^{94}$

However, learning diaguita in the Calchaquí valley was apparently not that easy. Few months after intalling in San Carlos, Torreblanca himself was complaining about the difficulties he still had to communicate:

[...] the Indians do not really want us to learn their language. It is also hard to create a method; even if the fist priests had worked, as demonstrated by their writings, it is something very difficult. ${ }^{95}$

It would be necessary to wait for the next decade before the Society could finally brag about the linguistic skills of their representatives in calchaquílands, who "perfectly learned their barbarian and difficult language" ${ }^{96}$ — for want of any spiritual result. Definitely, Torreblanca had to wait for Pedro Bohórquez to come to show up the whole extent of his lengua's talent, during the negotiations between the different parties. A cruel paradox, as a matter of a fact: those negotiations were precisely to cause the mission's brutal ending and to redirect the lonely bilingual missionary to castrensian tasks.

\section{Conclusions}

Speaking the enemy's language and finally becoming the most wanted expert, only enabled the missionary to accompany its speakers up to the disappearing of this language. After being defeated and spread throughout the four corners of the Tucumán and Río de la Plata, the diaguita populations, for reasons that are difficult to establish for sure, but certainly linked to the symbolic economy of colonial relationships and to the needs brought up by their new condition as a defeated lot, ended up in losing their language. Reduced in colonial establishments — farms or indigenous villages — where

\footnotetext{
${ }^{93}$ Other documents describe the attitudes of this character with the same terms: "declaration of Antonio Calderón, chief of the fort of Pantano, says he knows these Indians very well because he is a creole, born and raised in the city of San Juan de la Ribera, and that he is a witness of being the best orator of the language of the so called diaguitas". Aníbal Montes, "El gran alzamiento diaguita”, Revista del Instituto de Antropología, Universidad del Litoral, Rosario, n. 1, 1961, “Probanza para la entrada a Malfín”, p. 152.

${ }_{94}^{4}$ Hernando de Torreblanca, Relación Histórica de Calchaquí, Buenos Aires, AGN, 1999. [1696], p. 98.

${ }^{95}$ Pablo Pastells, "Carta del Provincial de la Cia de Jesús Fco de Lupercio de Zurbano a SM 1644, 19-12 (desde Bs Aires)", Historia de la Compañía de Jesús en la provincia del Paraguay, Madrid, Victoriano Suárez, 1912, vol. 2, t. 2, p. $96-101$.

96“Carta Anua 1653-1654”, In: Jaime Cortesão, Manuscritos da coleção de Angelis, t. II : Jesuítas e bandeirantes no Itatim (1596-1760), Rio de Janeiro, Biblioteca Nacional do Rio de Janeiro, 1952, p. 139.
} 
they lived not only among other ladinos of several origins, but also with mocovies and tobas prisoners captured in the organized raids across the Chaco, they had to count on new more general forms of expression. Using quéchua, undoubtedly, more and more Spanish, when it was not a curious mestizo mix in which kakán words would occupy less and less space.

A more detailed investigation would be necessary to follow thoroughly this evolution. A good indicator would be the systematic study of the documents related to the encomiendas and the judicial archives posterior to the deportation campaigns, in order to understand which type of treatment was reserved to the expelled people. A quick look into the records of the visit of judge Luján de Vargas to the encomiendas of the Tucumán, ${ }^{97}$ La Rioja and Jujuy, ${ }^{98}$ where many of the calchaquís had been "reduced" - a visit was almost contemporary to the writing of Relación Histórica de Calchaqui - raises two issues. First of all, these Indians appear now merely as "calchaquis", with no further mention of their exact origin. Secondly, even though two interpreters were actually appointed for the visit - the scrivener Lorenzo Pinto and the protector of Indians, Diego de Salazar y Benavidez (born in La Rioja) — the language they were supposed to use does not appear anywhere. Now, in several cases calchaquís and mocovies are actually questioned together ${ }^{99}$ and we know they did not speak the same tongue. It is worth asking then how, under these circumstances, these Indians could convey their complaints to the judges. Even if it is hard to determine for sure, it is clear that this type of legal device counted among the ones that influenced the defeated ones to adopt the colonial communication languages. As it shifted from being the enemy's language to the vanquished tongue, the kakán, gradually lost its autonomous framework of existence.

\footnotetext{
${ }^{97}$ Estela Noli, "Pueblos de indios, indios sin pueblos: Ios calchaquíes desnaturalizados en la visita de Luján de Vargas de 1693 a San Miguel de Tucumán”, Anales Nueva Época, 6, Göteborg, 2003, p. 330-363.

${ }^{98}$ Roxana Boixados y Carlos Zanolli, La visita de Luján de Vargas a las encomiendas de La Rioja y Jujuy (1693-1694), Quilmes, UNQ, 2003

${ }_{99}^{9}$ For instance, attend La Rioja, on July 2nd, 1693, Juan Calchaquí and Agustín Mocoví, Ibidem, p. 70.
} 